\title{
Physical, Chemical, Mechanical, and Biological Properties of Four Different Commercial Root-End Filling Materials: A Comparative Study
}

\author{
Tae-Yun Kang ${ }^{1,+} \mathbb{1}$, Ji-Won Choi ${ }^{1,2,+}$, Kyoung-Jin Seo ${ }^{1,2,+}$, Kwang-Mahn Kim ${ }^{1,2}$ and Jae-Sung Kwon ${ }^{1,2, *(1)}$ \\ 1 Department and Research Institute of Dental Biomaterials and Bioengineering, Yonsei University College of \\ Dentistry, Seoul 03722, Korea; tykang@yuhs.ac (T.-Y.K.); den0424@yuhs.ac (J.-W.C.); kjseo@yuhs.ac (K.-J.S.); \\ kmkim@yuhs.ac (K.-M.K.) \\ 2 BK21 FOUR Project, Yonsei University College of Dentistry, Seoul 03722, Korea \\ * Correspondence: jkwon@yuhs.ac; Tel.: +82-2-2228-3081 \\ + These authors contributed equally to this article.
}

Citation: Kang, T.-Y.; Choi, J.-W.; Seo, K.-J.; Kim, K.-M.; Kwon, J.-S. Physical, Chemical, Mechanical, and Biological Properties of Four Different Commercial Root-End Filling Materials: A Comparative Study. Materials 2021, 14, 1693. https://doi. org $/ 10.3390 /$ ma14071693

Academic Editor: Bruno Chrcanovic

Received: 3 March 2021

Accepted: 26 March 2021

Published: 30 March 2021

Publisher's Note: MDPI stays neutral with regard to jurisdictional claims in published maps and institutional affiliations.

Copyright: (c) 2021 by the authors. Licensee MDPI, Basel, Switzerland. This article is an open access article distributed under the terms and conditions of the Creative Commons Attribution (CC BY) license (https:/ / creativecommons.org/licenses/by/ $4.0 /)$.

\begin{abstract}
Commercial mineral trioxide aggregate (MTA) materials such as Endocem MTA (EC), DiaRoot Bio MTA (DR), RetroMTA (RM), and ProRoot MTA (PR) are increasingly used as root-end filling materials. The aim of this study was to assess and compare the physicochemical and mechanical properties and cytotoxicity of these MTAs. The film thicknesses of EC and DR were considerably less than that of PR; however, RM's film thickness was greater than that of PR. In addition, the setting times of EC, DR, and RM were shorter than that of PR $(p<0.05)$. The solubility was not significantly different among all groups. The three relatively new MTA groups (EC, DR, and RM) exhibited a significant difference in $\mathrm{pH}$ variation and calcium ion release relative to the PR group $(p<0.05)$. The radiopacity of the three new MTAs was considerably less than that of PR. The mechanical strength of RM was not significantly different from that of PR $(p>0.05)$; however, the EC and DR groups were not as strong as PR $(p<0.05)$. All MTA groups revealed cytocompatibility. In conclusion, the results of this study confirmed that EC, RM, DR, and PR exhibit clinically acceptable physicochemical and mechanical properties and cell cytotoxicity.
\end{abstract}

Keywords: mineral trioxide aggregate (MTA); root-end filling materials; endodontic materials; retrograde filling materials

\section{Introduction}

Calcium silicate-based cements (CSCs) have various indications for use in endodontics, and their clinical applications have increased over the years. Mineral trioxide aggregate (MTA) is a calcium silicate-based material commonly considered ideal for endodontic treatment due to its excellent biological and physicochemical properties [1-4]. The first commercially available MTA, Pro Root MTA (Dentsply, Tulsa, OK, USA), is composed of Portland cement and bismuth oxide [5,6].

MTA is recommended for a number of clinical applications in endodontic treatment, such as pulp capping, pulpotomy, apexification, apicogenesis, apical barrier, repair of root perforations, formation in teeth with necrotic pulps and open apexes, root-end filling, and orthograde root canal filling [1,4]. An ideal endodontic repair material should be biocompatible, easy to handle, insoluble in body fluids, economical, and dimensionally stable for long-term clinical success [1,4]. MTA has several advantages in terms of biocompatibility, bioactivity, sealing ability, and dimensional stability $[7,8]$.

Conventional MTA, ProRoot MTA (PR), has supplanted other endodontic materials because of its superior physico-chemical and biological properties that are due to its composition of fine hydrophilic powders of tricalcium silicate, tricalcium aluminate, tricalcium oxide, and other oxides $[1,4,9]$. Although it has a variety of favorable properties, conventional MTA (PR) has been reported to have several drawbacks in clinical settings because of 
its long setting time, expense, sensitivity to the presence of moisture, and low compressive strength compared with other endodontic treatments [1,4,10-13]. Since, PR sets relatively slowly, it may be washed out from the preparation under hemorrhagic conditions when it is used as a root-end filling material, which may cause treatment failure [1,9]. PR also has a discoloration potential, which can contribute to tooth discoloration, discoloration and it contains a variety of toxic elements. It is important to overcome conventional MTA's biocompatibility drawbacks $[1,9,14]$.

Recently, a new type of silicate-based MTA (Endocem MTA, Retro MTA, and Diaroot BioMTA) was developed to overcome these disadvantages when used as an endodontic treatment $[7,15,16]$. Endocem MTA (EC) contains fine particles of pozzolan, a calcium silicate-based material that reacts with calcium hydroxide (formed after a hydration reaction) and produces additional cementitious materials. EC has been reported to show biocompatibility similar to MTA, improve washout resistance, and cause less tooth discoloration $[7,9,17]$. Retro MTA (RM) was recently developed and introduced to the market as a new hydraulic calcium silicate-based material proposed for use in endodontic applications similar to those of MTA [18]. RM is a fast-setting MTA that consists of a calcium zirconia complex. According to the manufacturers, RM has less discoloration potential, is relatively cost-effective, and is easy to manipulate. Recently, a study showed that RM has similar biocompatibility to PR $[15,16,19-23]$. Dia Root Bio MTA (DR) is a newly improved calcium silicate-based MTA that is easy to manipulate and promotes cementogenesis and sealing capability inside the root canal system. However, only a limited amount of information is available on this product. Despite the increase in the use of MTA as an endodontic treatment material, there has been limited information on these new products in the previous literature [16].

A review of previous studies revealed no direct comparisons of these three commercial MTAs with PR. Thus, the purpose of this study was to assess and compare the physicochemical, mechanical properties, and cytotoxicity of these three new types of MTA with Pro Root MTA as a retrograde filling material. In the present study, we compared the three commercial MTAs with Pro Root MTA in terms of setting time, film thickness, solubility, radiopacity, $\mathrm{pH}$, the release of calcium ions, compressive strength, and cytotoxicity.

The null hypotheses of this study were; (1) There will be no significant differences in the physicochemical properties between any of the three new MTAs in comparison to PR, (2) There will be no significant differences in the mechanical properties between any of the three new MTAs in comparison to PR, (3) There will be no significant differences in the cytotoxicity between any of the three new MTAs in comparison to PR.

\section{Materials and Methods}

\subsection{Materials and Preparation of the Specimens}

Four commercially available MTAs were used in the present study (Table 1). Endo-cem MTA (EC) was mixed with sterile normal saline at a W/P ratio of 0.12 cc:300 mg, Dia-Root Bio MTA (DR) was mixed with sterile distilled water at a W/P ratio of $0.225 \mathrm{~g}: 0.5 \mathrm{~g}$, Retro MTA (RM) was mixed with provided liquid at a W/P ratio of 3 drops:0.3 g, and Pro Root MTA (PR) was mixed with provided liquid at a $\mathrm{W} / \mathrm{P}$ ratio of 3:1 as recommended instructions by the manufacturer. In addition, sterile normal saline (Cleancle, JW Pharmaceutical Co., Seoul, Korea) and sterile distilled water (sterilized distilled water for intermediate and external perfusion, JW Pharmaceutical Co., Seoul, Korea) were used to mix EC and DR, respectively. 
Table 1. Information on the four commercially available mineral trioxide aggregates (MTAs) used in the present study.

\begin{tabular}{ccc}
\hline Materials & Composition & Manufacturer \\
\hline $\begin{array}{c}\text { Endocem MTA } \\
(\text { EC })\end{array}$ & $\begin{array}{c}\text { Tricalcium silicate, tricalcium aluminate, } \\
\text { dicalcium silicate, bismuth oxide }\end{array}$ & $\begin{array}{c}\text { Maruchi, } \\
\text { Wonju, Korea }\end{array}$ \\
\hline $\begin{array}{c}\text { Dia-Root Bio MTA } \\
\text { (DR) }\end{array}$ & $\begin{array}{c}\text { Calcium silicate, amorphous fumed silica, } \\
\text { zirconium dioxide }\end{array}$ & $\begin{array}{c}\text { Diadent, } \\
\text { Cheongju, Korea }\end{array}$ \\
\hline $\begin{array}{c}\text { Retro MTA } \\
(\text { RM })\end{array}$ & $\begin{array}{c}\text { Calcium carbonate, silicon dioxide, } \\
\text { aluminium oxide, calcium zirconia complex }\end{array}$ & $\begin{array}{c}\text { BioMTA, } \\
\text { Seoul, Korea }\end{array}$ \\
\hline $\begin{array}{c}\text { Pro Root MTA } \\
(\text { PR })\end{array}$ & $\begin{array}{c}\text { Portland cement, bismuth oxide, calcium } \\
\text { sulfate dihydrate, tetracalcium } \\
\text { aluminoferrite, gypsum, calcium oxide }\end{array}$ & $\begin{array}{c}\text { Dentsply, } \\
\text { Tulsa, TN, USA }\end{array}$ \\
\hline
\end{tabular}

\subsection{Film Thickness, Setting Time, and Solubility}

The film thickness, setting time and solubility tests of the materials were measured based on the International Organization for Standardization (ISO) 6876 standard methods. To investigate the film thickness, two flat glass plates with $25 \mathrm{~mm}$ square (contact surface area of approximately $625 \pm 50 \mathrm{~mm}^{2}$ ) were combined to measure the thickness of the two glass plates in contact. Three minutes after starting the mixing, a load of $150 \mathrm{~N}$ was applied vertically on the upper plate. Ten minutes after the start of mixing, the thickness to an accuracy of $1 \mu \mathrm{m}$ of the space between the two glass plates that was filled with experimental material was measured using a digital caliper (Mitutoyo Model CD-15CPX; Mitutoyo Co., Kawasaki, Japan). The test was repeated 3 times for each group.

To analyze the setting time, the initial and final setting times were measured by evaluating the absence of indentations caused by Gillmore needles. The mixed experimental material was filled into a mold with internal diameter of $20 \mathrm{~mm}$ and height of $2 \mathrm{~mm}$. Before the test, all the apparatus was conditioned for $24 \mathrm{~h}$ under 100\% relative humidity at $37 \pm 1{ }^{\circ} \mathrm{C}$. The setting time test was performed under $100 \%$ relative humidity at a temperature of $37 \pm 1{ }^{\circ} \mathrm{C}$ using the Gillmore needle. Each of the two indenters with flat ends and a mass of $100 \pm 0.5 \mathrm{~g}$ (initial setting time) or $453.6 \mathrm{~g}$ (final setting time) were loaded vertically onto the top surface of the specimens. The test was repeated 3 times for each group.

To measure the solubility, the mixed experimental material was placed in a mold with $20 \mathrm{~mm}$ diameter and $2 \mathrm{~mm}$ height, and the excess was removed. The filled mold was placed under $100 \%$ relative humidity at $37 \pm 1{ }^{\circ} \mathrm{C}$ for $7 \mathrm{~d}$. For each tested experimental material, two specimens were used (total $6, n=3)$. The initial mass of the two specimens $\left(\mathrm{m}_{0}\right)$ and the container $\left(\mathrm{M}_{0}\right)$ were measured to the nearest $0.001 \mathrm{~g}$ by an analytical balance (XS105, Mettlertoledo AG, Greifensee, Switzerland). The two specimens were immersed in $50 \mathrm{~mL}$ distilled water and placed in a water bath maintained at $37 \pm 1^{\circ} \mathrm{C}$ for $24 \mathrm{~h}$. After $24 \mathrm{~h}$, the specimen was removed from the container, washed with distilled water, and then placed in an oven at $80 \pm 2{ }^{\circ} \mathrm{C}$ for drying. Subsequently, the desiccator was cooled and weighed to determine the final mass $\left(\mathrm{M}_{1}\right)$. The final mass of each specimen was deter-mined, and the loss of mass was calculated by the following equation:

$$
\text { Solubility }(\%)=100 \times\left(\mathrm{M}_{1}-\mathrm{M}_{0}\right) / \mathrm{m}_{0}
$$

\subsection{Radiopacity}

Radiopacity evaluation of the set materials was performed using the ISO 6876 and 13116. Each mixed MTA material was filled into a mold $10.0 \pm 1.0 \mathrm{~mm}$ in diameter and $1.0 \pm 0.1 \mathrm{~mm}$ height. To obtain the radiographic images, both specimens and an aluminum step wedge were placed on a digital sensor and exposed to an X-ray unit (Carestream CS7600, Siemens, Munich, Germany) at $65 \pm 5 \mathrm{kV}$ and $10 \mathrm{~mA}$ with a $300 \pm 100 \mathrm{~mm}$ focus-film distance. The grey pixel values of each specimen were determined using the 
Photoshop program (Adobe, San Jose, CA, USA), and the equivalent radiopacity of the cement sample was calculated in $\mathrm{mm}$ of aluminum ( $\mathrm{Al} \mathrm{mm}$ ).

\subsection{Compressive Strength at 7 Days}

Each MTA materials was mixed and filled into a mold $4 \mathrm{~mm}$ in diameter and $8 \mathrm{~mm}$ in height. Seven cylindrical samples for each group were prepared. The specimens were incubated under $100 \%$ relative humidity at a temperature of $37 \pm 1{ }^{\circ} \mathrm{C}$. The specimens for compressive strength were ground with a wet 600 grit $7 \mathrm{~d}$ after preparation. A computercontrolled universal testing machine (Model 3366; Instron ${ }^{\circledR}$, Norwood, MA, USA) was used to compress the specimens. The compressive strength was measured at a crosshead speed of $0.25 \mathrm{~mm} / \mathrm{min}$.

The maximum load of the compressive strength was recorded and calculated in MPa as:

$$
\mathrm{CS}=4 \mathrm{P} / \pi D^{2}
$$

where CS is the compressive strength, $p$ is the maximum force applied in Newtons $(\mathrm{N})$, and $D$ is the mean diameter of the specimen in millimeters $(\mathrm{mm})$.

\section{5. $\mathrm{pH}$, Calcium Ion Release, and Bioactivity}

To analyze the $\mathrm{pH}$ variation of the soaking solution and calcium ion release, each MTA material was prepared and filled into a mold with an internal diameter of $10 \mathrm{~mm}$ and a height of $1 \mathrm{~mm}$. After filling, the specimen was stored at $37 \pm 1{ }^{\circ} \mathrm{C}$ for $24 \mathrm{~h}$. The specimen was separated from the mold and was then immersed in $10 \mathrm{~mL}$ of Hank's balanced salt solution (HBSS; H6648, Sigma Aldrich, St. Louis, MO, USA) [24]. A pH meter (Orion 4 Star, Thermo Fisher Scientific Inc., Singapore) calibrated using buffer solutions of $\mathrm{pH} 4.01,7.00$, and 10.01 was used. The $\mathrm{pH}$ variation of the HBSS-immersed specimen was measured at $3 \mathrm{~h}, 6 \mathrm{~h}, 24 \mathrm{~h}, 72 \mathrm{~h}$, and $168 \mathrm{~h}$.

The same solutions used to test the $\mathrm{pH}$ variation were used to test for calcium ion release. After $168 \mathrm{~h}$, to analyze calcium ion release from the specimens, the HBSS was filtered with a $0.22-\mu \mathrm{m}$ syringe filter (DISMIC 25CS, Advantec, Osaka, Japan) and subjected to inductively coupled plasma optical emission spectrometry (ICP-OES, Optima 8300, PerkinElmer, Waltham, MA, USA). The measurements of the $\mathrm{pH}$ and calcium ion release were repeated 3 times, and mean and standard deviations were used.

The morphology of the specimens before and after immersion in HBSS solution was analyzed by field emission scanning electron microscopy (FE-SEM, MERLIN, Carl Zeiss, Oberkochen, Germany) after ion sputtering (Leica EM ACE600) to coat the specimen with platinum.

\subsection{Cell Viability}

Mouse fibroblast cells (L929; CRL-6364; ATCC, Manassas, VA, USA) were cultured in RPMI 1640 (Welgene, Daegu, Korea) supplemented with 10\% fetal bovine serum and 1\% antibiotics under standard cell culture conditions $\left(37^{\circ} \mathrm{C}, 100 \%\right.$ humidity, $95 \%$ air, $\left.5 \% \mathrm{CO}_{2}\right)$. L929 cells were seeded in a 96-well plate at a density of $1 \times 10^{4}$ cells/well and incubated for $24 \mathrm{~h}$ under standard cell culture conditions.

The specimen of each MTA material was formed under aseptic conditions in a sterile cylindrical mold $5 \mathrm{~mm}$ in diameter and $2 \mathrm{~mm}$ high and sterilized using ultraviolet irradiation (UV) for $30 \mathrm{~min}$ before storage in an incubator at $37 \pm 1{ }^{\circ} \mathrm{C}$ for $24 \mathrm{~h}$ to achieve complete setting. The ratio of material surface area to medium volume was set at approximately $3 \mathrm{~cm}^{2} / \mathrm{mL}$ in accordance with the ISO 10993-5 and $12[25,26]$.

The extraction medium was filtered through a $0.22 \mu \mathrm{m}$ syringe filter, and three concentrations $(50 \%, 25 \%$, and $12.5 \%)$ were prepared and applied to the cells. At $24 \mathrm{~h}$, the cytotoxicity was determined using a 3-(4,5-dimethylthiazol-2-yl)-2,5-diphenyltetrazolium bromide (MTT; Sigma-Aldrich, St. Louis, MO, USA) assay. MTT solution was added to the cells and incubated at $37^{\circ} \mathrm{C}$ for $2 \mathrm{~h}$ in the dark. The MTT solution was then removed, and $100 \mu \mathrm{L}$ of dimethyl sulfoxide (0231, VWR Life Science, Radnor, PA, USA) was added to 
each well. The optical density (OD) at $570 \mathrm{~nm}$ was measured using a plate reader (Epoch, BioTek, Winooski, VT, USA). The experiments were performed in triplicate.

\subsection{Statistical Analysis}

The results of film thickness, setting time, solubility, radiopacity, compressive strength, $\mathrm{pH}$ variation, calcium ion release, and cell viability were analyzed using the SPSS 25 software program (IBM Corp., Armonk, NY, USA). To calculate the mean and standard deviation (SD), descriptive statistics was conducted. In addition, to analyze the significant difference among the MTA groups, one-way analysis of variance (ANOVA) and Tukey's honest significant difference (HSD) test were performed. $p$-vales less than 0.05 were considered statistically significant.

\section{Results}

\subsection{Film Thickness, Setting Time, and Solubility}

Table 2 shows the means, standard deviations, and statistical comparisons of the film thickness, setting time, and solubility tests of the commercial materials studied.

Table 2. Means \pm standard deviation (SD) for film thickness, setting time, solubility, and compressive strength.

\begin{tabular}{cccccc}
\hline & Film Thickness & \multicolumn{2}{c}{ Setting Time } & Solubility & $\begin{array}{c}\text { Compressive } \\
\text { Strength }\end{array}$ \\
\cline { 2 - 6 } Materials & $(\mathbf{m m})$ & $\begin{array}{c}\text { Initial Setting } \\
(\mathbf{m i n})\end{array}$ & $\begin{array}{c}\text { Final Setting } \\
(\mathbf{m i n})\end{array}$ & $\mathbf{( \% )}$ & $\mathbf{( M P a )}$ \\
\hline EC & $0.28 \pm 0.16^{\mathrm{a}}$ & $4.45 \pm 0.05^{\mathrm{b}}$ & $16.60 \pm 1.15^{\mathrm{b}}$ & $8.11 \pm 11.40^{\mathrm{a}}$ & $20.33 \pm 12.54^{\mathrm{b}}$ \\
DR & $0.26 \pm 0.07^{\mathrm{a}}$ & $27.24 \pm 0.88^{\mathrm{d}}$ & $49.31 \pm 2.60^{\mathrm{c}}$ & $2.23 \pm 0.33^{\mathrm{a}}$ & $20.64 \pm 9.25^{\mathrm{b}}$ \\
RM & $0.96 \pm 0.18^{\mathrm{c}}$ & $3.05 \pm 0.05^{\mathrm{a}}$ & $4.43 \pm 0.12^{\mathrm{a}}$ & $0.89 \pm 0.31^{\mathrm{a}}$ & $65.69^{\mathrm{a}} \pm 27.26^{\mathrm{a}}$ \\
PR & $0.58 \pm 0.05^{\mathrm{b}}$ & $18.53 \pm 0.42^{\mathrm{c}}$ & $122.67 \pm 6.43^{\mathrm{d}}$ & $0.82 \pm 0.34^{\mathrm{a}}$ & $68.21 \pm 16.22^{\mathrm{a}}$ \\
\hline
\end{tabular}

Different lowercase superscript letters indicate statistically significant differences between MTA groups $(p<0.05)$.

The mean film thickness values of EC, DR, RM, and PR were $0.28,0.26,0.96$, and $0.58 \mathrm{~mm}$, respectively. RM had the thickest film, and EC and DR had the thinnest films among the tested groups $(p<0.05)$.

Regarding initial setting times, RM had the shortest initial setting time, and DR had the longest setting time $(p<0.05)$. Additionally, RM had the shortest final setting time, and PR had the longest final setting time $(p<0.05)$. RM presented the lowest mean final setting time values among the materials tested $(p<0.05)$, followed by EC, DR, and PR $(p<0.05)$.

For the results of the solubility test, no significant differences were observed among the evaluated materials $(p>0.05)$. EC showed the highest value over $3 \%(8.11 \%)$.

\section{2. $p H$ Variation, Calcium Ion Release, and Bioactivity}

The means, standard deviations, and statistical comparisons for $\mathrm{pH}$ and calcium ion release $(\mathrm{mg} / \mathrm{L})$ are shown in Table 3 . The $\mathrm{pH}$ values measured for $\mathrm{DR}$ were slightly higher at all time points. $\mathrm{PR}$ had a lower $\mathrm{pH}$ value than the other groups during the initial period $(3,6$, and $24 \mathrm{~h})$. After $72 \mathrm{~h}$, all of the materials had similar $\mathrm{pH}$ values, except for $\mathrm{EC}$, which showed lower $\mathrm{pH}$ values $(p<0.05)$. DR and $\mathrm{RM}$ had the highest $\mathrm{pH}$, followed by $\mathrm{PR}$ and $\mathrm{EC}$, at $168 \mathrm{~h}(p<0.05)$. Only RM showed a statistically significant difference in relation to the interaction between the storage solution and materials at all times $(p<0.05)$. There was no significant difference between the $\mathrm{pH}$ values obtained for all groups at $168 \mathrm{~h}$ immersion time $(p>0.05)$. 
Table 3. $\mathrm{pH}$ variation and calcium ion release $(\mathrm{mg} / \mathrm{L})$ in soaking solution for 7 days.

\begin{tabular}{|c|c|c|c|c|c|c|}
\hline \multirow[b]{2}{*}{ Materials } & \multicolumn{6}{|c|}{$\mathrm{pH}$ and Calcium Release in Soaking Water (Means \pm SD) } \\
\hline & $3 \mathrm{~h}$ & $6 \mathrm{~h}$ & $24 \mathrm{~h}$ & $72 \mathrm{~h}$ & $168 \mathrm{~h}$ & $\begin{array}{c}\text { Ca Ions } \\
\text { Concentration } \\
\text { at } 7 \text { Days }(\mathrm{mg} / \mathrm{L})\end{array}$ \\
\hline $\mathrm{EC}$ & $11.58 \pm 0.01 \mathrm{ABab}$ & $11.63 \pm 0.07 \mathrm{ABab}$ & $11.28 \pm 0.05 \mathrm{Cb}$ & $11.49 \pm 0.08^{\mathrm{Bb}}$ & $11.70 \pm 0.01^{\mathrm{Ac}}$ & $76.33 \pm 2.93^{c}$ \\
\hline DR & $12.13 \pm 0.10 \mathrm{BCa}$ & $12.30 \pm 0.06^{\mathrm{ABa}}$ & $12.07 \pm 0.07 \mathrm{Ca}$ & $12.19 \pm 0.05 \mathrm{ABCa}$ & $12.33 \pm 0.07 \mathrm{Aa}$ & $377.34 \pm 52.19^{a}$ \\
\hline RM & $11.09 \pm 0.09 \mathrm{Eab}$ & $11.28 \pm 0.04^{\mathrm{Dbc}}$ & $11.85 \pm 0.09 \mathrm{Ca}$ & $12.13 \pm 0.01 \mathrm{Ba}$ & $12.38 \pm 0.05 \mathrm{Aa}$ & $346.78 \pm 92.14^{\mathrm{ab}}$ \\
\hline PR & $10.20 \pm 0.48^{\mathrm{Cb}}$ & $10.66 \pm 0.65^{\mathrm{BC} c}$ & $11.42 \pm 0.17 \mathrm{ABb}$ & $12.01 \pm 0.30 \mathrm{ACa}$ & $11.97 \pm 0.06^{\mathrm{Ab}}$ & $215.16 \pm 62.25^{\mathrm{cb}}$ \\
\hline
\end{tabular}

Different uppercase superscript letters indicate statistically significant differences between immersion times $(p<0.05$, in the same line).

Different lowercase superscript letters indicate statistically significant differences between MTA groups ( $p<0.05$, in the same column).

With regard to the release of calcium ions, all materials released considerable amounts at 7 days. Additionally, the results of the ICP-OES analysis showed that RM and PR had significantly more calcium release than EC and DR $(p<0.05)$.

The morphology of the surfaces formed after the $\mathrm{pH}$ test of each of the samples can be assessed using the SEM images presented in Figure 1. SEM analysis revealed the presence of precipitates with various morphologies (Figure 1). All specimens had prismatic, hexagonal, cubical, needle-like, globular-like, petal-like, and scale-like crystalline precipitates on their surface (Figure 1A-D), which were not revealed in specimens that had not been immersed in HBSS (Figure 1E-H).

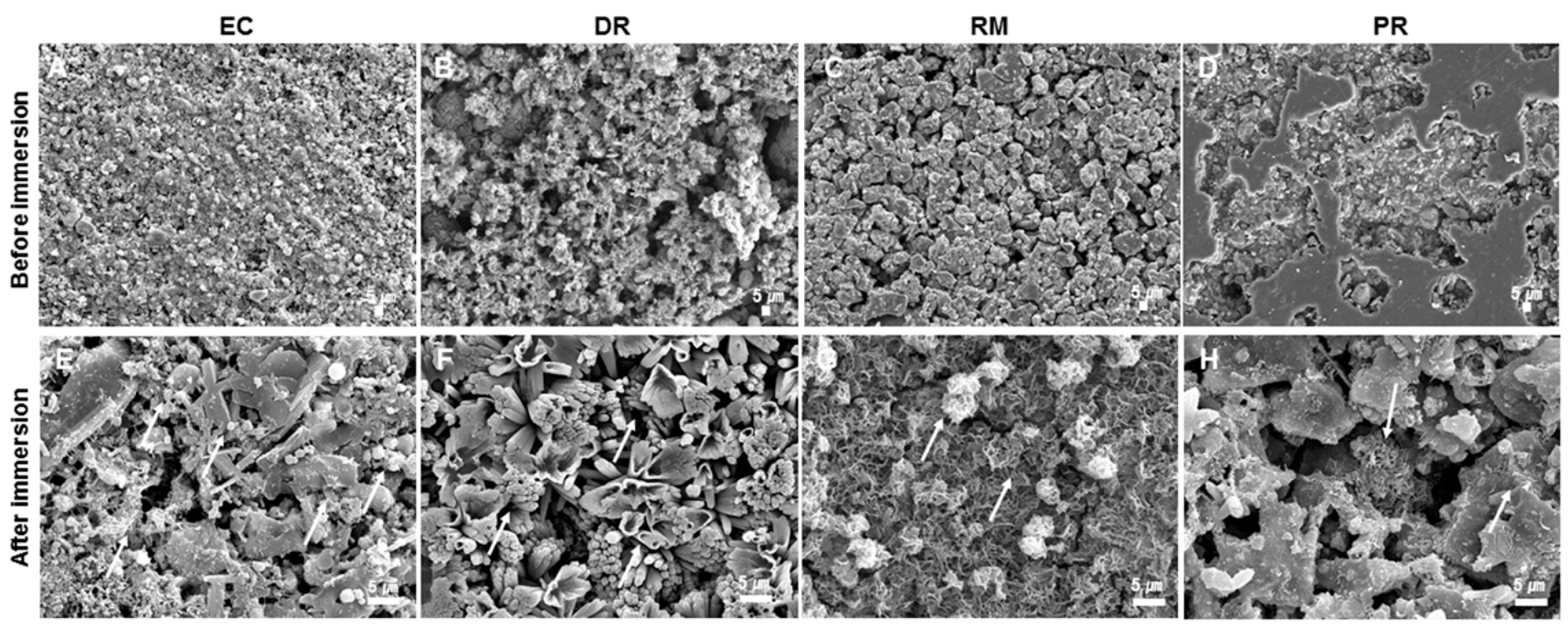

Figure 1. Scanning electron microscopy analysis of (A) Endocem MTA (EC), (B) Dia-Root Bio MTA (DR), (C) Retro MTA (RM), and (D) Pro Root MTA (PR) before immersion in Hank's balanced salt solution (HBSS) (500× magnification). Surface precipitates on sets (E) EC, (F) DR, (G) RM, and (H) PR produced after immersion in HBSS for $7 \mathrm{~d}(2000 \times$ magnification). Scale bar represents $5 \mu \mathrm{m}$.

\subsection{Radiopacity}

The results for the radiopacity values are presented in Figure 2. All MTA groups achieved the minimum required radiopacity value of $3 \mathrm{~mm}$ of $\mathrm{Al}$, as recommended by the ISO 6876 standard. PR showed the highest radiopacity values among the tested materials $(p<0.05)$, equivalent to $4.97 \mathrm{Al} \mathrm{mm}$. The EC, DR, and RM groups were not significantly different among the tested MTA groups regarding their radiopacity $(p>0.05)$. The radiopacity of EC, DR, and RM were equivalent to $4.06,3.88$, and $3.84 \mathrm{Al} \mathrm{mm}$, respectively. 


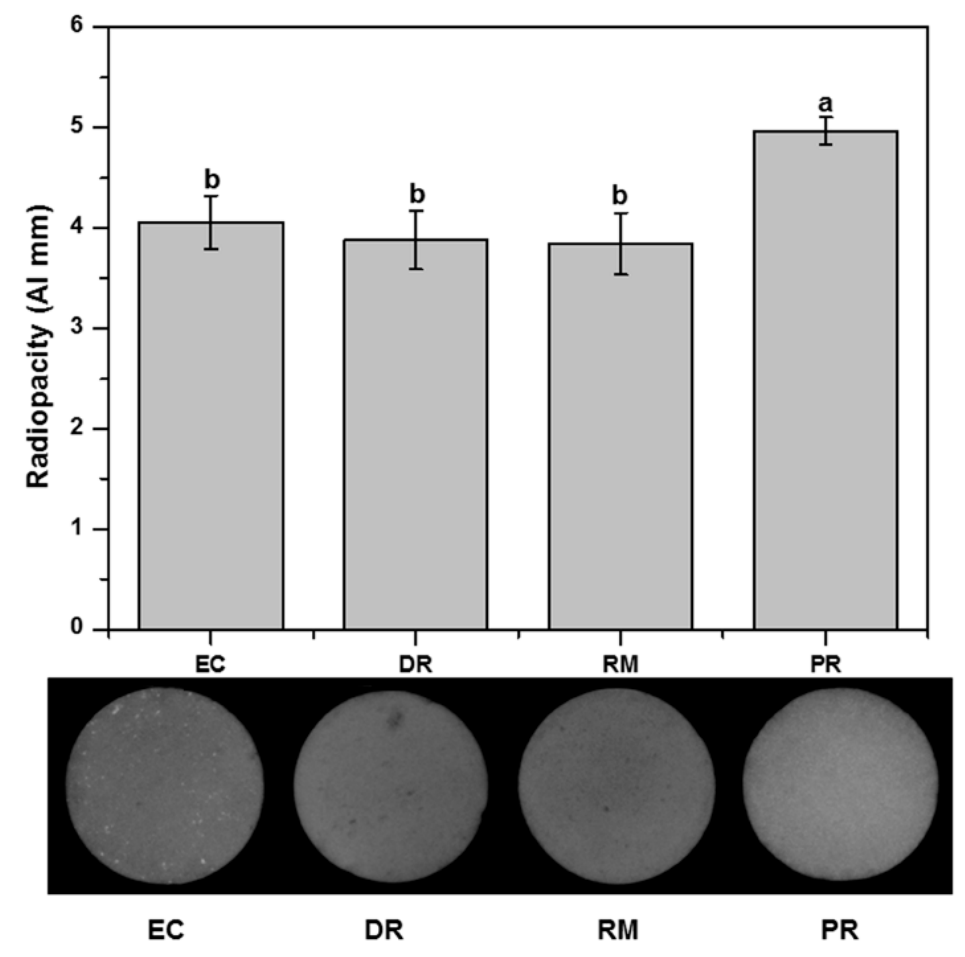

Figure 2. The radiopacity of the specimens was expressed as the equivalent thickness of aluminum $(\mathrm{mm} \mathrm{Al})$, and radiographic images of the specimens were obtained. The same lowercase letters indicate statistically significant differences $(p<0.05)$.

\subsection{Compressive Strength at 7 Days}

After $7 \mathrm{~d}$ of setting, the specimens were tested for compressive strength (MPa). The results for the mechanical properties of the specimens are presented in Table 2. Overall, the compressive strength values of PR (mean $=62.70 \pm 15.92 \mathrm{MPa})$ and RM (mean = $77.48 \pm 22.49 \mathrm{MPa}$ ) were significantly greater than those of EC (mean $=18.51 \pm 9.18 \mathrm{MPa}$, $p<0.05$ ) and $\mathrm{DR}$ (mean $=23.45 \pm 9.65 \mathrm{MPa}, p<0.05)$. PR was not significantly different in compressive strength from RM $(p>0.05)$, and EC was not significantly different in compressive strength from DR $(p>0.05)$.

\subsection{Cell Cytotoxicity}

The cell cytotoxicity of the extract from four MTA specimens at different extract concentrations is shown in Figure 3. The cells cultured on MTA eluates for $24 \mathrm{~h}$ were measured by MTT assays, considering cells cultured in the absence of the specimen extract as a blank control. When all specimen extract concentrations were diluted to $50 \%$, an effect on fibroblast cell cytotoxicity was detected (below 70\%), and when the extract concentration was diluted to $25 \%$ or lower, no effect on cell viability was shown (above $70 \%$ ). EC eluents, diluted 50\%, exhibited higher cell viability than the other MTA groups $(p<0.05)$. The viability of cells treated with EC, RM, and PR was similar in the 25 and $12.5 \%$ diluted extracts $(p>0.05)$. The viability of cells treated with DR was significantly lower than those treated with PR in 25 and $12.5 \%$ diluted extracts $(p<0.05)$, whereas there was no significant difference in cell viability compared with EC and RM $(p>0.05)$. Additionally, for DR, cells incubated in $12.5 \%$ diluted extract had significantly lower cell viability than cells incubated at the same extract concentrations of the other groups $(p<0.05)$. Cell viability was significantly affected in the presence of a dilution factor between $50 \%$ and $25 \%(p<0.05)$; however, there was no significant difference between $25 \%$ and $12.5 \%(p<0.05)$. For all MTA groups, significant differences were detected between the $50 \%$ and $25 \%$ dilutions $(p<0.05)$. As expected, extract dilution in medium decreased MTA cytotoxicity. 


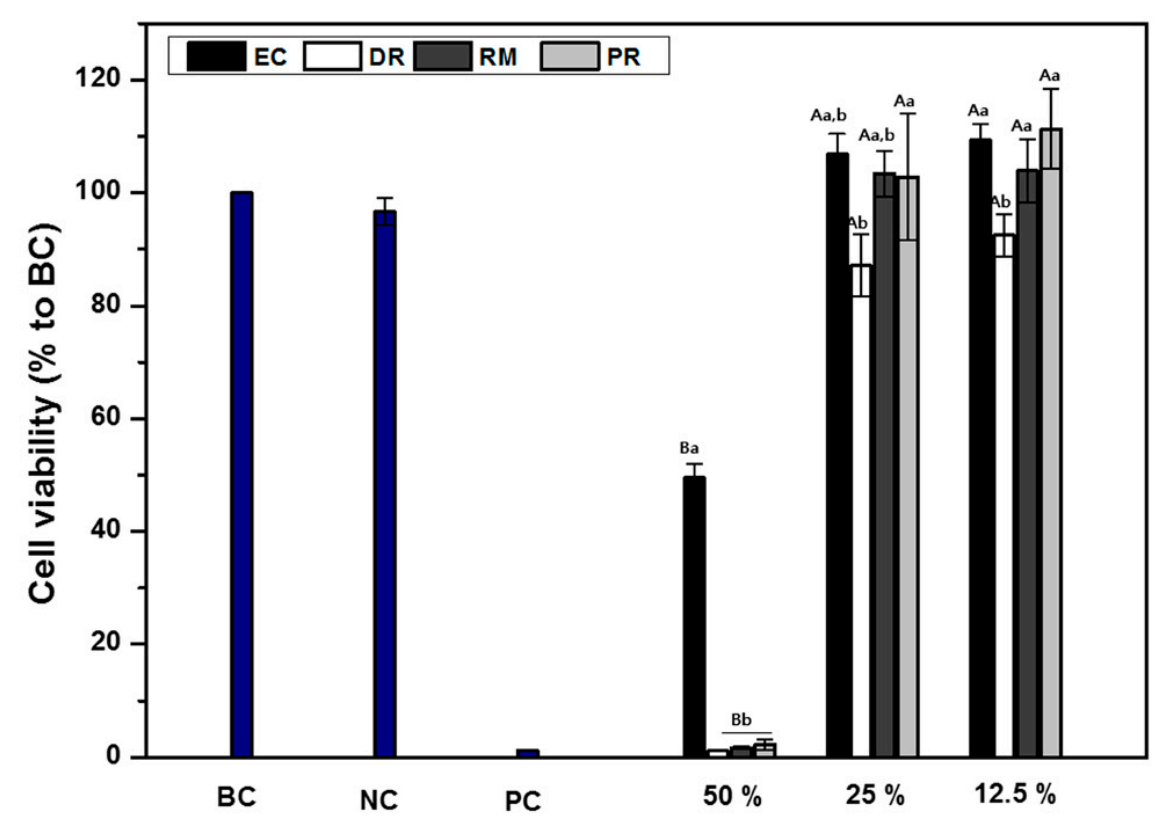

Figure 3. Cytotoxicity with the extracts from commercial MTA as measured by the MTT assay. The same uppercase letters indicate statistically significant differences in the dilution factor within each material $(p<0.05)$. The same lowercase letters indicate statistically significant differences within each MTA group $(p<0.05)$. BC, blank control; NC, negative control; PC, positive control.

\section{Discussion}

When nonsurgical endodontic treatment fails or cannot be performed, surgical root canal treatment should be conducted. This surgical procedure includes the placement of a retrograde filling material in close contact with the peri-radicular tissue. Therefore, the physical and chemical properties as well as the biocompatibility of the retrograde filling material are very important for the success of apical surgery [26]. Generally, MTA is considered the gold standard material in clinical applications. Several previous studies found that MTA as a root-end filling material had excellent physicochemical properties and demonstrated its supremacy over other commonly used materials [26-28].

Recently, several new MTA-based endodontic treatment materials were introduced to improve clinical practice $[9,13,17,29-31]$. We evaluated the physicochemical and mechanical properties and cell cytotoxicity of three new commercial MTAs in comparison with conventional MTA (PR).

The physical properties of MTA, such as setting time, film thickness, and solubility, strongly affect the material's clinical performance. In particular, these properties are important clinical factors affecting their sealing ability. For instance, the thicker the film, the lower the chance of material penetration into the accessory root canal system [32]. Several previous works reported that a thinner layer of sealer positively affected the sealing ability of the root canal filling [33-35]. In this study, the results showed that all MTA groups had a thinner film than PR $(p<0.05)$, except for RM $(p>0.05)$.

A long setting time of materials provides an adequate working time when performing surgical treatment, such as retrograde filling or perforation repairs. However, in certain clinical situations, such as apexification and particularly apical surgery, unset material may be washed out by body fluid and/or blood in the surgical field, which may lead to treatment failure and cytotoxicity [36-39].

A fast setting time for materials ensures that the MTA has the least amount of interaction time with the contaminants present in the oral cavity, making it easier to place a second restorative material on top of the MTA $[36,40,41]$. The MTA setting time could be a factor that is directly related to surgical root canal treatment success [39]. Hence, in some clinical conditions, an accelerated setting time is required to avoid dissolution of the materials under oral conditions [36]. The results of this study confirmed that the final setting time 
of the three new MTAs was shorter than that of PR $(p<0.05)$. A previous study reported that the proper setting time is considered to be 10 and $15 \mathrm{~min}$ in clinical situations [36]. This result is in agreement with a previous setting time test and indicates that both EC and RM had the proper setting time $[7,15,16,18]$. The main advantage of RM over PR includes its reduced setting time because of the fast setting of its calcium silicate-based materials, which form calcium zirconia complexes $[15,16]$. The EC group sets quickly without the addition of a chemical accelerator because it contains fine-particle pozzolan cement $[6,42]$.

Solubility is an acceptable property for endodontic treatment materials, since it allows the release of ions. However, it is important that excess solubilization of the material does not occur [43]. Most endodontic failures occur as a result of the leakage of irritants from pathologically involved root canals into the periapical tissues [44]. Hence, endodontic and restorative materials should also have a long-term seal and prevent leakage from the oral cavity and/or the periapical tissue [45]. To provide long-term stability and prevent microleakage from the periapical tissue, root-end filling material must have a low solubility [44]. Thus, a low solubility in distilled water, as proposed in the Standard of the International Standard Organization (ISO) 6876, is required [46]. Following this test, the weight loss of each specimen is indicated as the percentage of the original mass, and the ideal recommendation is a value less than $3 \%[45,46]$.

Radiopacity is a very important characteristic required for pulp treatment materials [47]. Root-end filling and endodontic repair materials must have radiopacity to allow for evaluation of the quality of the filling for patient safety. A radiopaque material is essential to identify the location of the material in the root canal and to allow for filling failures to be corrected before final restoration [48]. MTA with a radiopacity value lower than $3 \mathrm{~mm} \mathrm{Al}$ is hardly distinguishable from dentine. Clinically acceptable values of radiopacity, i.e., higher than $3 \mathrm{~mm} \mathrm{Al}$, are mandatory for controlling the quality of root canal filling [43,49]. In the present study, all MTA groups achieved the minimum required radiopacity value of $3 \mathrm{~mm}$ of $\mathrm{Al}$, as recommended by the ISO 6876 standard.

When MTA contacts fluids, it rapidly releases calcium and hydroxyl ions and creates an alkaline $\mathrm{pH}$ on its external surface, leading to the nucleation and crystallization of apatite on the material's surface [50,51]. Numerous previous studies reported that MTA has the ability to form calcium phosphate apatite crystals on its surface after contact with phosphate-containing simulated body fluid solution [50-52]. Consequently, the deposition of calcium and phosphate apatite into voids and spaces between the dentin, root canal systems, and root filling material enables MTA to encourage regeneration and remineralization of adjacent hard tissues while also improving its sealing capacity [50,53,54]. Thus, apatite-forming ability may provide clinical advantages by improving the sealing via the deposition of apatite at the interface and inside the dentinal tubules of the root canal when MTA is used as a root canal filling material $[13,50,54]$. HBSS solution was used in the present study as a storage solution to simulate the clinical environment. In this study, all materials showed alkalinizing activity and the formation of crystalline apatite on the surface of the specimens.

MTA is a hydraulic cement consisting of fine hydrophilic particles that gradually harden in a wet environment $[11,55]$. The compressive strength of MTA which was set for 28 days is considered an indicator of the progression of the hydration reaction and a reflection of the setting process. In this study, compressive strength of each sample was measured following 7 days of storage. The number of days of storage was determined in accordance to a draft of ISO 6876 that is currently under revision and in order to compare MTA following adequate hydration. Still, the study is limited as the optimal days of storage were not predetermined which would have resulted in a higher level of compressive strength. In accordance with clinical perspectives, a greater compressive strength of MTA is considered to be an important feature when this material is used as pulp capping or as a coronal restorative material when it is submitted to occlusal and mastication forces [56]. However, when MTA is used as a root-end filling material, where minimal forces are applied, a low compressive strength will not be a major clinical drawback $[40,57]$. 
Cell cytotoxicity of endodontic materials is of great concern because irritation of the surrounding tissue can affect periapical tissue regeneration $[22,58,59]$. In an in vitro study, after application in medium, MTA suffers a hydration reaction that results in the formation of calcium hydroxide and subsequent ionic dissociation into calcium and hydroxyl ions, which is responsible for an increase in $\mathrm{pH}$ value and an elevated calcium concentration in the cell medium [60]. In this study, the four commercial MTAs maintained a cell viability rate above $70 \%$ for all dilutions, except for the $50 \%$ diluted eluent. When comparing the cell cytotoxicity of the four commercial MTAs in this study, PR resulted in the highest cell viability, and DR was significantly more cytotoxic than the other two types $(p<0.05)$. This cytotoxic effect of DR may be attributed to the differences in the initial amount of various ions released from the materials. Additionally, another factor may be caused by the characteristics of the DR material itself, which can increase the $\mathrm{pH}$ value. According to the manufacturer, DR has a strong antibacterial effect with a high alkaline $\mathrm{pH}$ (above $\mathrm{pH}$ 12). However, the DR group achieved the minimum required recommendation of a $70 \%$ relative cell viability rate, as recommended by the ISO 10993-5 standard.

In terms of the initial null hypotheses of this study, the hypothesis about their physicochemical properties was partially accepted. When the PR group was compared with the $\mathrm{EC}, \mathrm{DR}$, and RM groups, the results of this study showed statistically significant differences in film thickness, setting time, $\mathrm{pH}$ variation, calcium ion release, and radiopacity $(p<0.05)$, although no significant differences were found for the solubility $(p>0.05)$. However, their solubility was not significantly different from that of the PR group $(p>0.05)$. The second null hypothesis was partially rejected because the EC and DR groups revealed a significant difference in compressive strength $(p<0.05)$ when compared to the PR group; however, the $\mathrm{RM}$ group revealed no significant difference compared to PR $(p>0.05)$. Finally, when the three new MTAs were compared with PR, the results of this study showed a statistically significant difference in cell cytotoxicity for all dilutions $(p<0.05)$. Therefore, the third null hypothesis was rejected.

This study has several limitations. This in vitro study could not sufficiently simulate the clinical situation, which involves a complex and variable biomechanical environment. Also, as stated earlier, some of the methods are based on ISO 6876 where clinical relevance may be different between conventional root canal filling material and MTA. Thus, additional studies are needed for long-term and simulated clinical situation evaluations while such limitations are also something that would be useful when considering revision of the current version of ISO 6876.

\section{Conclusions}

In conclusion, the present study confirmed that EC, RM, and DR exhibit clinically acceptable physicochemical and mechanical properties and cell cytotoxicity relative to PR. Therefore, we confirmed that the EC, RM, and DR have the physicochemical and biocompatible characteristics that could be alternatives to conventional MTA as a retrograde filling material.

Author Contributions: Conceptualization, J.-S.K., T.-Y.K., J.-W.C., and K.-J.S.; methodology, J.-S.K. and T.-Y.K.; validation, K.-M.K., J.-S.K. and T.-Y.K.; formal analysis, T.-Y.K., J.-W.C., and K.-J.S.; investigation, T.-Y.K., J.-W.C., and K.-J.S.; resources, K.-M.K. and J.-S.K.; data curation, J.-S.K. and T.-Y.K.; writing —original draft preparation, T.-Y.K., J.-W.C., and K.-J.S.; writing—review and editing, J.-S.K. and T.-Y.K.; visualization, J.-S.K. and T.-Y.K.; supervision, J.-S.K. and T.-Y.K.; project administration, J.-S.K., and T.-Y.K.; funding acquisition, J.-S.K. All authors have read and agreed to the published version of the manuscript.

Funding: This work was supported by the Korea Medical Device Development Fund grant funded by the Korea government (Project Number: 9991007149, KMDF_PR_20200901_0045).

Institutional Review Board Statement: Not applicable.

Informed Consent Statement: Not applicable. 
Data Availability Statement: Data is contained within the article.

Conflicts of Interest: The authors declare no conflict of interest.

\section{References}

1. Parirokh, M.; Torabinejad, M. Mineral Trioxide Aggregate: A comprehensive literature review-Part III: Clinical applications, drawbacks, and mechanism of action. J. Endod. 2010, 36, 400-413. [CrossRef]

2. Bosso-Martelo, R.; Guerreiro-Tanomaru, J.M.; Viapiana, R.; Berbert, F.L.C.; Duarte, M.A.H.; Tanomaru-Filho, M. Physicochemical properties of calcium silicate cements associated with microparticulate and nanoparticulate radiopacifiers. Clin. Oral Investig. 2016, 20, 83-90. [CrossRef] [PubMed]

3. Torabinejad, M.; Rastegar, A.F.; Kettering, J.D.; Pitt Ford, T.R. Bacterial leakage of mineral trioxide aggregate as a root-end filling material. J. Endod. 1995, 21, 109-112. [CrossRef]

4. Roberts, H.W.; Toth, J.M.; Berzins, D.W.; Charlton, D.G. Mineral trioxide aggregate material use in endodontic treatment: A review of the literature. Dent. Mater. 2008, 24, 149-164. [CrossRef] [PubMed]

5. Torabinejad, M.; White, D.J. Tooth Filling Material and Method of Use. U.S. Patent US5769638A, 16 May 1995.

6. Setbon, H.; Devaux, J.; Iserentant, A.; Leloup, G.; Leprince, J. Influence of composition on setting kinetics of new injectable and/or fast setting tricalcium silicate cements. Dent. Mater. 2014, 30, 1291-1303. [CrossRef]

7. Choi, Y.; Park, S.-J.; Lee, S.-H.; Hwang, Y.-C.; Yu, M.-K.; Min, K.-S. Biological effects and washout resistance of a newly developed fast-setting pozzolan cement. J. Endod. 2013, 39, 467-472. [CrossRef]

8. Thomson, T.S.; Berry, J.E.; Somerman, M.J.; Kirkwood, K.L. Cementoblasts maintain expression of osteocalcin in the presence of mineral trioxide aggregate. J. Endod. 2003, 29, 407-412. [CrossRef] [PubMed]

9. Kim, M.; Yang, W.; Kim, H.; Ko, H. Comparison of the biological properties of ProRoot MTA, OrthoMTA, and Endocem MTA cements. J. Endod. 2014, 40, 1649-1653. [CrossRef]

10. Bogen, G.; Kuttler, S. Mineral trioxide aggregate obturation: A review and case series. J. Endod. 2009, 35, 777-790. [CrossRef]

11. Torabinejad, M.; Hong, C.U.; McDonald, F.; Pitt Ford, T.R. Physical and chemical properties of a new root-end filling material. J. Endod. 1995, 21, 349-353. [CrossRef]

12. Islam, I.; Kheng Chng, H.; Jin Yap, A.U. Comparison of the physical and mechanical properties of MTA and portland Cement. J. Endod. 2006, 32, 193-197. [CrossRef]

13. Gandolfi, M.G.; Siboni, F.; Primus, C.M.; Prati, C. Ion release, porosity, solubility, and bioactivity of MTA plus tricalcium silicate. J. Endod. 2014, 40, 1632-1637. [CrossRef] [PubMed]

14. Tawil, P.Z.; Duggan, D.J.; Galicia, J.C. Mineral trioxide aggregate (MTA): Its history, composition, and clinical applications. Compend. Contin. Educ. Dent. 2015, 36, 247-264. [PubMed]

15. Kang, S.-H.; Shin, Y.-S.; Lee, H.-S.; Kim, S.-O.; Shin, Y.; Jung, I.-Y.; Song, J.S. Color changes of teeth after treatment with various mineral trioxide aggregate-based materials: An ex vivo study. J. Endod. 2015, 41, 737-741. [CrossRef]

16. Lee, H.; Shin, Y.; Kim, S.-O.; Lee, H.-S.; Choi, H.-J.; Song, J.S. Comparative study of pulpal responses to pulpotomy with ProRoot MTA, RetroMTA, and TheraCal in dogs' teeth. J. Endod. 2015, 41, 1317-1324. [CrossRef]

17. Jang, J.-H.; Kang, M.; Ahn, S.; Kim, S.; Kim, W.; Kim, Y.; Kim, E. Tooth discoloration after the use of new pozzolan cement (Endocem) and mineral trioxide aggregate and the effects of internal bleaching. J. Endod. 2013, 39, 1598-1602. [CrossRef]

18. Souza, L.C.D.; Yadlapati, M.; Dorn, S.O.; Silva, R.; Letra, A. Analysis of radiopacity, pH and cytotoxicity of a new bioceramic material. J. Appl. Oral Sci. 2015, 23, 383-389. [CrossRef]

19. Chung, C.J.; Kim, E.; Song, M.; Park, J.-W.; Shin, S.-J. Effects of two fast-setting calcium-silicate cements on cell viability and angiogenic factor release in human pulp-derived cells. Odontology 2016, 104, 143-151. [CrossRef] [PubMed]

20. Kang, E.-H.; Yoo, J.-S.; Kim, B.-H.; Choi, S.-W.; Hong, S.-H. Synthesis and hydration behavior of calcium zirconium aluminate $\left(\mathrm{Ca}_{7} \mathrm{ZrAl}_{6} \mathrm{O}_{18}\right)$ cement. Cem. Concr. Res. 2014, 56, 106-111. [CrossRef]

21. Li, Q.; Deacon, A.D.; Coleman, N.J. The impact of zirconium oxide nanoparticles on the hydration chemistry and biocompatibility of white portland cement. Dent. Mater. J. 2013, 32, 808-815. [CrossRef]

22. Kang, T.Y.; Seo, J.Y.; Ryu, J.H.; Kim, K.M.; Kwon, J.S. Improvement of the mechanical and biological properties of bioactive glasses by the addition of zirconium oxide $\left(\mathrm{ZrO}_{2}\right)$ as a synthetic bone graft substitute. J. Biomed. Mater. Res. Part A 2020. [CrossRef]

23. Camilleri, J. Characterization and hydration kinetics of tricalcium silicate cement for use as a dental biomaterial. Dent. Mater. 2011, 27, 836-844. [CrossRef]

24. Eldeniz, A.; Mustafa, K.; Ørstavik, D.; Dahl, J. Cytotoxicity of new resin-, calcium hydroxide-and silicone-based root canal sealers on fibroblasts derived from human gingiva and L929 cell lines. Int. Endod. J. 2007, 40, 329-337. [CrossRef]

25. ISO 10993-5. In Biological Evaluation of Medical Devices-Part 5: Test for In Vitro Cytotoxicity; International Organization for Standardization: Geneva, Switzerland, 2009.

26. Torabinejad, M.; Watson, T.; Ford, T.P. Sealing ability of a mineral trioxide aggregate when used as a root end filling material. J. Endod. 1993, 19, 591-595. [CrossRef]

27. Fischer, E.J.; Arens, D.E.; Miller, C.H. Bacterial leakage of mineral trioxide aggregate as compared with zinc-free amalgam, intermediate restorative material, and Super-EBA as a root-end filling material. J. Endod. 1998, 24, 176-179. [CrossRef]

28. De-Deus, G.; Canabarro, A.; Alves, G.; Marins, J.; Linhares, A.; Granjeiro, J. Cytocompatibility of the ready-to-use bioceramic putty repair cement iRoot BP Plus with primary human osteoblasts. Int. Endod. J. 2012, 45, 508-513. [CrossRef] 
29. Fakheran, O.; Birang, R.; Schmidlin, P.R.; Razavi, S.M.; Behfarnia, P. Retro MTA and tricalcium phosphate/retro MTA for guided tissue regeneration of periodontal dehiscence defects in a dog model: A pilot study. Biomater. Res. 2019, 23, 1-7. [CrossRef]

30. Gandolfi, M.; Siboni, F.; Prati, C. Chemical-physical properties of TheraCal, a novel light-curable MTA-like material for pulp capping. Int. Endod. J. 2012, 45, 571-579. [CrossRef] [PubMed]

31. Gandolfi, M.G.; Taddei, P.; Siboni, F.; Modena, E.; Ciapetti, G.; Prati, C. Development of the foremost light-curable calcium-silicate MTA cement as root-end in oral surgery. Chemical-physical properties, bioactivity and biological behavior. Dent. Mater. 2011, 27, e134-e157. [CrossRef] [PubMed]

32. Estrela, C.; Bammann, L.L.; Estrela, C.R.d.A.; Silva, R.S.d.; Pecora, J.D. Antimicrobial and chemical study of MTA, Portland cement, calcium hydroxide paste, Sealapex and Dycal. Braz. Dent. J. 2000, 11, 3-9.

33. De-Deus, G.; Coutinho-Filho, T.; Reis, C.; Murad, C.; Paciornik, S. Polymicrobial leakage of four root canal sealers at two different thicknesses. J. Endod. 2006, 32, 998-1001. [CrossRef]

34. Georgopoulou, M.K.; Wu, M.-K.; Nikolaou, A.; Wesselink, P.R. Effect of thickness on the sealing ability of some root canal sealers. Oral Surg. Oral Med. Oral Pathol. Oral Radiol. Oral Endod. 1995, 80, 338-344. [CrossRef]

35. Wu, M.K.; De Gee, A.; Wesselink, P. Leakage of four root canal sealers at different thicknesses. Int. Endod. J. 1994, 27, 304-308. [CrossRef]

36. Ber, B.S.; Hatton, J.F.; Stewart, G.P. Chemical modification of ProRoot MTA to improve handling characteristics and decrease setting time. J. Endod. 2007, 33, 1231-1234. [CrossRef]

37. Pornamazeh, T.; Yadegari, Z.; Ghasemi, A.; Sheykh-Al-Eslamian, S.M.; Shojaeian, S. In vitro cytotoxicity and setting time assessment of calcium-enriched mixture cement, retro mineral trioxide aggregate and mineral trioxide aggregate. Iran. Endod. J. 2017, 12, 488-492. [PubMed]

38. Lee, S.-J.; Chung, J.; Na, H.-S.; Park, E.-J.; Jeon, H.-J.; Kim, H.-C. Characteristics of novel root-end filling material using epoxy resin and Portland cement. Clin. Oral Investig. 2013, 17, 1009-1015. [CrossRef]

39. Camilleri, J.; Montesin, F.; Di Silvio, L.; Pitt Ford, T. The chemical constitution and biocompatibility of accelerated Portland cement for endodontic use. Int. Endod. J. 2005, 38, 834-842. [CrossRef] [PubMed]

40. Bernardi, A.; Bortoluzzi, E.; Felippe, W.; Felippe, M.; Wan, W.; Teixeira, C. Effects of the addition of nanoparticulate calcium carbonate on setting time, dimensional change, compressive strength, solubility and pH of MTA. Int. Endod. J. 2017, 50, 97-105. [CrossRef]

41. Ding, S.J.; Kao, C.T.; Shie, M.Y.; Hung, C., Jr.; Huang, T.H. The physical and cytological properties of white MTA mixed with Na2HPO4 as an accelerant. J. Endod. 2008, 34, 748-751. [CrossRef]

42. Köseoğlu, S.; Pekbağryank, T.; Kucukyilmaz, E.; Sağlam, M.; Enhos, S.; Akgün, A. Biological response of commercially available different tricalcium silicate-based cements and pozzolan cement. Microsc. Res. Tech. 2017, 80, 994-999. [CrossRef]

43. Almeida, L.H.S.; Moraes, R.R.; Morgental, R.D.; Cava, S.S.; Rosa, W.L.O.; Rodrigues, P.; Ribeiro, A.S.; Só, M.; Pappen, F.G. Synthesis of silver-containing calcium aluminate particles and their effects on a MTA-based endodontic sealer. Dent. Mater. 2018, 34, e214-e223. [CrossRef]

44. Fogel, H.M.; Peikoff, M.D. Microleakage of root-end filling materials. J. Endod. 2001, 27, 456-458. [CrossRef]

45. Kaup, M.; Schäfer, E.; Dammaschke, T. An in vitro study of different material properties of Biodentine compared to ProRoot MTA. Head Face Med. 2015, 11, 16. [CrossRef]

46. ISO 6876. In Dentistry-Root Canal Sealing Materials; International Organization for Standardization: Geneva, Switzerland, 2012.

47. Guerreiro-Tanomaru, J.M.; Duarte, M.A.H.; Gonçalves, M.; Tanomaru-Filho, M. Radiopacity evaluation of root canal sealers containing calcium hydroxide and MTA. Braz. Oral Res. 2009, 23, 119-123. [CrossRef] [PubMed]

48. Duarte, M.A.H.; D’arc de Oliveira El, G.; Vivan, R.R.; Tanomaru, J.M.G.; Tanomaru Filho, M.; de Moraes, I.G. Radiopacity of portland cement associated with different radiopacifying agents. J. Endod. 2009, 35, 737-740. [CrossRef]

49. Guimarães, B.M.; Tartari, T.; Marciano, M.A.; Vivan, R.R.; Mondeli, R.F.L.; Camilleri, J.; Duarte, M.A.H. Color stability, radiopacity, and chemical characteristics of white mineral trioxide aggregate associated with 2 different vehicles in contact with blood. $J$. Endod. 2015, 41, 947-952. [CrossRef] [PubMed]

50. Camilleri, J.; Formosa, L.; Damidot, D. The setting characteristics of MTA Plus in different environmental conditions. Int. Endod. J. 2013, 46, 831-840. [CrossRef] [PubMed]

51. Gandolfi, M.; Taddei, P.; Tinti, A.; Prati, C. Apatite-forming ability (bioactivity) of ProRoot MTA. Int. Endod. J. 2010, 43, 917-929. [CrossRef]

52. Gandolfi, M.G.; Taddei, P.; Tinti, A.; Dorigo, E.D.S.; Rossi, P.L.; Prati, C. Kinetics of apatite formation on a calcium-silicate cement for root-end filling during ageing in physiological-like phosphate solutions. Clin. Oral Investig. 2010, 14, 659-668. [CrossRef]

53. Holland, R.; De Souza, V.; Nery, M.J.; Otoboni Filho, J.A.; Bernabé, P.F.; Dezan, E., Jr. Reaction of rat connective tissue to implanted dentin tubes filled with mineral trioxide aggregate or calcium hydroxide. J. Endod. 1999, 25, 161-166. [CrossRef]

54. Gandolfi, M.; Parrilli, A.; Fini, M.; Prati, C.; Dummer, P.M.H. 3D micro-CT analysis of the interface voids associated with Thermafil root fillings used with AH Plus or a flowable MTA sealer. Int. Endod. J. 2013, 46, 253-263. [CrossRef] [PubMed]

55. Camilleri, J. Evaluation of selected properties of mineral trioxide aggregate sealer cement. J. Endod. 2009, 35, 1412-1417. [CrossRef] [PubMed]

56. Machado, D.F.M.; Bertassoni, L.E.; Souza, E.M.D.; Almeida, J.B.D.; Rached, R.N. Effect of additives on the compressive strength and setting time of a Portland cement. Braz. Oral Res. 2010, 24, 158-164. [CrossRef] [PubMed] 
57. Prasad, A.; Pushpa, S.; Arunagiri, D.; Sawhny, A.; Misra, A.; Sujatha, R. A comparative evaluation of the effect of various additives on selected physical properties of white mineral trioxide aggregate. J. Conserv. Dent. 2015, 18, 237-241.

58. Kogan, P.; He, J.; Glickman, G.N.; Watanabe, I. The Effects of vVarious additives on setting properties of MTA. J. Endod. 2006, 32, 569-572. [CrossRef]

59. Koh, E.T.; McDonald, F.; Ford, T.R.P.; Torabinejad, M. Cellular response to mineral trioxide aggregate. J. Endod. 1998, $24,543-547$. [CrossRef]

60. Parirokh, M.; Torabinejad, M. Mineral trioxide aggregate: A comprehensive literature review—part I: Chemical, physical, and antibacterial properties. J. Endod. 2010, 36, 16-27. [CrossRef] 